the Centre National des Recherches. It is proposed to make systematic sound recordings of African languages, starting in the first instance with the languages of Cameroun français, and it is hoped by this means to secure phonetic material which will be of use to this Institute in connexion with the Handbook of African Languages on which work is now in progress. The material recorded will be based on certain questionnaires formulated by Dr. Tucker of the School of Oriental and African Studies. M. Nicolas, Directeur of IFAN Cameroun, has addressed a memorandum to the International African Institute describing the aims and scope of the project, the techniques and methods to be employed, and the procedure for presenting results. He suggests that similar enterprises might be undertaken by other organizations in other areas of Africa and the results collated.

\title{
Gramophone Records of African Music
}

THe Musée de l'Homme, Paris, has assembled a collection of records of African music prepared by M. C. Rouget, of the Département d'Éthnologie musicale, in collaboration with the Office de la Recherche Scientifique d'Outre-mer. The records comprise a selection of those made by M. A. Didier, of the Conservatoire National des Arts et Métiers, during his expedition to the Congo area in 1946, and include examples of the music of twenty-three native peoples in the Lower Congo, Gabon, Oubangui-Chari, and of two pygmy tribes of the Lower Congo-in all ro3 recordings representative of all types of African music: instrumental, both solo and orchestral, as well as vocal and choral specimens both with and without instrumental accompaniment. Certain ceremonial performances of the pygmies have been recorded in their entirety; one of these, which occupies eight records, reveals very clearly the architectural quality of this music, the motive of which is participation in a magical and religious cult.

All the recordings were made in the field and out-of-doors, but they are not inferior in quality to studio recordings and the characteristic tone quality of African music has been faithfully reproduced. The name and geographical location of the people concerned, as well as the instrumental or vocal character of the music, is indicated on each record.

The complete set of thirty-four records is available for sale at i 5,000 francs (exclusive of packing and postage): only fifty sets have been made, and no records will be sold separately. Orders should be addressed to: Département d'Éthnologie musicale, Musée de l'Homme, Palais de Chaillot, Paris.

\section{Organisme d'enquête pour l'étude anthropologique des populations indigènes de I'A.O.F.}

AN account of the 'Mission Anthropologique' which has been at work from January 1946 to August 1948 in French West Africa, has been published by its director, Médecin Lt.-Colonel Léon Pales. The mission made a comprehensive study of the native populations of French West Africa, mainly from the point of view of nutrition and health. Within the range of its inquiries it included anthropometric, physiological, and biochemical studies, as well as psychological, pathological, and ethnological researches, and detailed analyses of food consumption and production, including nutritive values, preparation and conservation of food-stuffs.

The work of the mission was carried out in part by laboratory and documentary work, in part by tours in the field. Four separate tours were undertaken in Sénégal, Soudan occidental, Guinée occidentale, and Haute Volta-Côte d'Ivoire-Fouta Djalon. A great number of families and individuals, including school children and hospital patients, were examined, and reports on special aspects or particular sections of the work were published during the course of the investigation. Some of these have already been noticed in this Journal (xviii, 2 and 3, 1948). 